\title{
同時荷重印加における見掛け強度分布への厚み偏差の影響
}

\author{
須貝和人 ・岸本 昭* ・中村吉伸* • 元平直文 $*$ 柳田博明* \\ 水澤化学工業(株)，103 東京都中央区日本橋室町 4-1-21 \\ *東京大学工学部応用化学科, 113 東京都文京区本郷 7-3-1
}

\section{Influence of Thickness Deviation on the Apparent Strength Distribution from Simultaneous Loading System}

\author{
Kazuhito SUGAI, Akira KISHIMOTO*, Yoshinobu NAKAMURA*, \\ Naobumi MOTOHIRA* and Hiroaki YANAGIDA*
}

Mizusawa Chemical Co., Ltd., 4-1-21, Nihonbashi-Muromachi, Chuo-ku, Tokyo 103

*Department of Applied Chemistry, Faculty of Engineering, The University of Tokyo, 7-3-1, Hongo, Bunkyo-ku, Tokyo

[Received March 17, 1995; Accepted August 24, 1995]

The effect of thickness deviation on the apparent strength distribution through simultaneous loading measurement was estimated. Some thickness deviations were generated by computer simulation. An apparent strength was calculated from the intrinsic strength of a sample and thickness difference taking into account of the sample setup of the simultaneous loading measurement. For a hundred samples with thickness deviation which accords with a normal distribution, the apparent strength distribution was calculated based on Weibull statistics and compared to the ideal one. Almost equivalent strength distribution shape was proved to be obtainable from samples with standard deviation of thickness deviation up to $6.5 \mu \mathrm{m}$ in the case of titanium dioxide ceramics. This critical thickness deviation was larger than $1 \mu \mathrm{m}$ for all ceramic materials calculated, which could be controllable using a micrometer.

Key-words : Thickness deviation, Apparent strength distribution, Computer simulation, Simultaneous loading system, Weibull statistics

1. 緒言

著者らは既に複数同時荷重印加による，強度分布の評価 方法を提案している11,2)。この試験方法では，複数の試験 片に同時に荷重を印加するため，試験片の形状にばらつき があると，真の強度分布形を得ることが困難になると考え られる。

試験片の形状，特に厚さが不均一であると見掛けの破壞 時間が実際の破壞時間より長くなる。これは本評価法に最 も大きな影響を及ぼす要因になると考えられる，そこで本 研究では, 試験片の形状のうち厚さについて, 特に検討を 行った.

試験片の厚さに基準となる厚さからのへだたり，すなわ ち厚み偏差があると考え, 本評価法で得られる見掛け強度 分布にどのように影響するか検討した。 その結果, 試験片 にある程度厚久偏差を導入しても, 複数同時荷重印加に よって得られる強度分布形には影響ないことが分かったの
で，以下に報告する.

\section{2. 実 験}

\section{1 実験背景}

著者らが提案している複数同時荷重印加試験による強度 分布の評価では, 試験片の形状は均一であるとした．複数 同時荷重印加試験装置を図 1 に示す。この同時荷重印加試 験では，試験片を支持軸に垂直に 10 本並べ，支持軸と平 行に調整したクロスヘッドを一定の速度で降下させ，試験 片に荷重が掛かりはじめてからの時間を測定する。更に， 試験片に定電圧を印加し，モニタリングした電流値の変化 からある時間経過後の試料の破壊確率を知ることができ た．複数同時荷重印加試験による強度分布の評価は，同一 形状の試料に，一定速度でクロスヘッドを降下させること により，破壞応力を破壊までの時間（破壊時間）により代 替することで可能となった。

もしここで試験片の厚さが不均一であった場合, 図 1 の側面図で示すように最も厚い試験片から荷重が掛かるこ とになる。

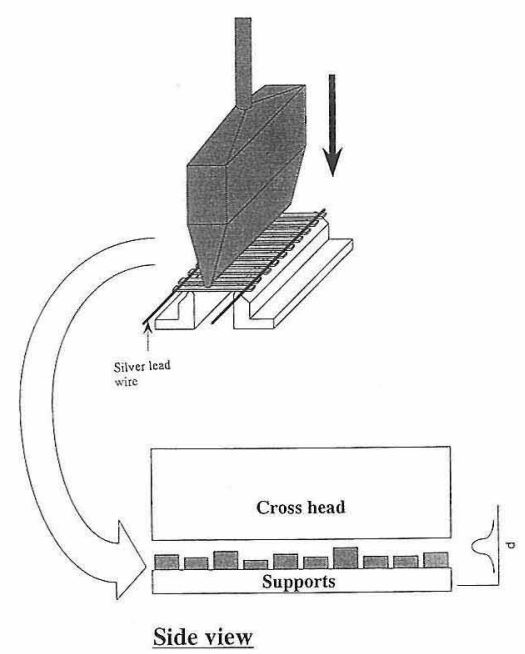

Fig. 1. Schematic sample setup for simultaneous loading and side view. 
破壊時間の測定もこの時点で始まり，見掛けの破壊時間 が測定され，見掛けのたわみ変位が求められる.ある試験 片の見掛けのたわみ変位は, 最大の厚さの試験片との差の 分だけ大きくなる．これによって，見掛けの破壞応力が計 算され, ワイブル分布から強度分布形を示すワイブル係数 が求まる. 本研究では，基準となる厚さからのへだたり (厚み偏差) が，正規分布となるように計算機により発生 させ，試験片の厚さの差による見掛けの破壊たわ及変位か ら見掛け破壊応力を求めて強度分布への影響を調べた。な お試験装置の剛性は十分大きく, かつ付加治具その他の精 度は高く計算結果に影響を及ぼさないものとした。

\section{2 厚み偏差の見掛け強度分布への影響}

正規分布に基づいた厚み偏差を発生させ, 試験片の厚さ をランダムにばらつかせた。このときの試験片の厚み分布 幅による強度分布への影響を調べた. シミェレーションに はチタニアセラミックスを想定した2)。平均曲げ強度は $80 \mathrm{MPa}$ ，ヤング率は $210 \mathrm{GPa}$ ，ワイブル係数は10とした。 試験片の形状は, 長さ $40 \mathrm{~mm}$, 幅 $5.0 \mathrm{~mm}$, 厚さ $0.3 \mathrm{~mm}$ とした、まず，100個の試験片についてワイブル式

$$
p=1-\left\{\exp -\left(\frac{\sigma}{\sigma_{0}}\right)^{m} V\right\}
$$

に基づき $m=10, \bar{\sigma}_{\mathrm{r}}=80 \mathrm{MPa}$ を基準とする破壊応力 $(\sigma)$ を発生させた．ここで $m$ は想定した真のワイブル係数, $\sigma_{0}$ は尺度母数, $V$ は有効体積である.

$$
\bar{\sigma}_{\mathrm{r}}=\sigma_{0} V^{-1 / m}\left(\frac{m+1}{m}\right)
$$

(2)式により， $\bar{\sigma}_{\mathrm{r}}=80 \mathrm{MPa}$ と関連づけた。ただし，「は ガンマ関数である。この破壊応力とヤング率 $(E)$ から

$$
\begin{aligned}
\sigma & =\frac{3 P L}{2 b d^{2}} \\
E & =\frac{L^{3} P}{4 b d^{3} u}
\end{aligned}
$$

（3）式，(4)式より真の破壊たわみ変位（ $\left.u_{\mathrm{r}}\right)$ を求めた．た だし， $P$ は破壊荷重, $L$ はスパン幅 $(30 \mathrm{~mm}), b$ は試験片 の幅, $d$ は厚さを表す。

所定の標準偏差となるように厚み偏差を発生させ, 基準 厚さ $(0.3 \mathrm{~mm})$ を加えおのおのの試験片の厚さとした。 次いで試験片を 10 本を 1 組として，10組に分けた．各組 につき，それぞれの試験片の真の破壊たわ久变位 $\left(u_{\mathrm{r}}\right)$ と その試験片と10本のうち最大厚さの試験片との厚さの差 $(\Delta d)$ の和を見掛けの破壊たわ久变位 $\left(u_{\mathrm{a}}=u_{\mathrm{r}}+\Delta d\right)$ と した.これとヤング率から見掛けの破壊応力 $\left(\sigma_{\mathrm{a}}\right)$ を求め た.これを 10 組行い，100本の試験片の見掛け破壊応力か らワイブル分布を得た.この分布から最小二乗法によりワ イブル係数を計算した.

厚み偏差の標準偏差は 0 から0.001，0.005，0.008，0.01， $0.02,0.05(\mathrm{~mm})$ と変化させ, 各厚み偏差の標準偏差ごと に10回乱数を発生させてワイブル係数を求めた.

\section{3 厚み偏差が見掛け強度分布に及ぼす影響の基準厚 さ依存性と各種セラミックスへの影響}

チタニア試験片の厚さを変えた場合, ワイブル係数に影
響を与える厚み偏差の標準偏差の臨界値を求め, 試験片の 厚さとの関係を調べた。シミュレーションの方法は 2.2 節 と同様に行った.

また 2.2 節と同様のシミュレーションを，各種セラミッ クスについて行い, ワイブル係数への厚み偏差の影響を検 討した．試験片の形状ならびにワイブル係数は2.2節に基 づいた.

\section{3. 結 果}

\section{1 チタニアのワイブル係数への厚さの偏差の影響}

厚久偏差の標準偏差を変えて, 試験片の厚さをばらつか せたときの，見掛けの強度のワイブル分布の変化を図 2 に 示す。厚久偏差の標準偏差が大きくなると，ワイブル分布 の傾きが小さくなり，見掛けの破壊応力は大きくなること が分かる．各厚み偏差の標準偏差ごとに10回乱数を発生 させ，ワイブル係数の平均值を求めた. このワイブル係数 の平均值と試験片の厚み偏差の標準偏差との関係を図 3 に 示す. エラーバーは, 得られたワ.イブル係数の標準偏差を 示す.

厚み偏差の標準偏差が0.0065 mm 付近までは, ワイブ

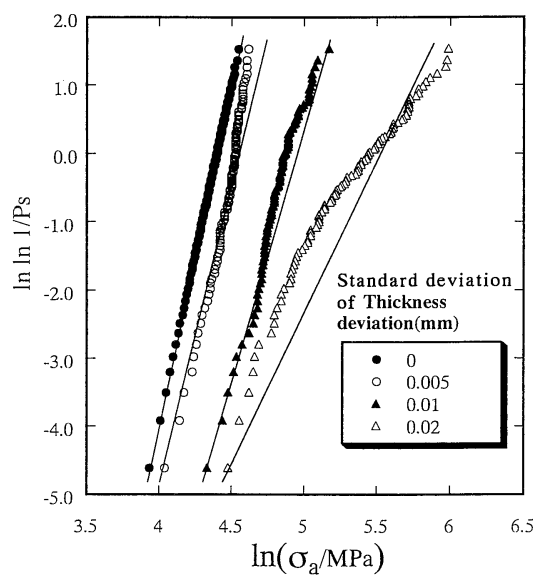

Fig. 2. Change of apparent Weibull distribution with various standard deviation of thickness deviation for $\mathrm{TiO}_{2}$ ceramics.

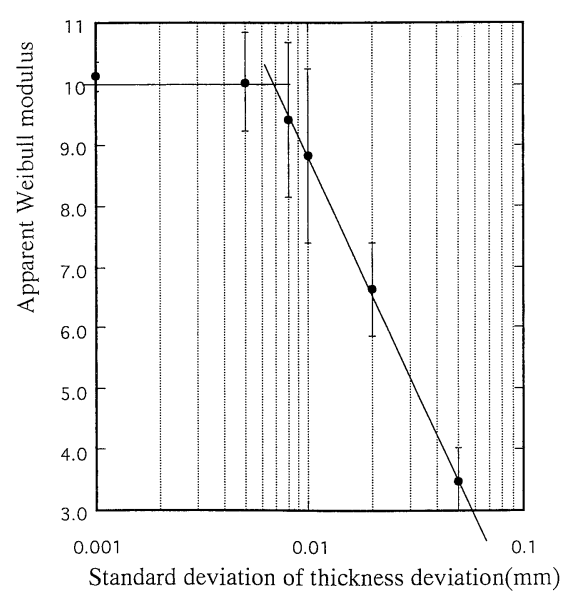

Fig. 3. Change in apparent Weibull modulus with various standard deviation of thickness deviation for $\mathrm{TiO}_{2}$ ceramics. 
ル係数は10を維持し,この係数の標準偏差が徐々に増加 していくことが分かる. 試験片の厚及偏差の標準偏差が $0.0065 \mathrm{~mm}$ 以上になるとワイブル係数が厚み偏差の標準 偏差の対数に対して直線的に低下することが分かる.この 結果より, ワイブル係数が 10 を維持できる厚み偏差の標 準偏差の臨界值があることが分かった（以下, 臨界厚み偏 差と表現する).

チタニアセラミックスを用いた時のワイブル係数 $m=$ 10 に対して, 厚及偏差の標準偏差は $0.0065 \mathrm{~mm}$ まで, つ まり厚さの $2.2 \%$ までは許容範囲であることが分かる. 試 験片の厚さの測定をマイクロメーターで行った場合, $0.001 \mathrm{~mm}$ まで測定できるので複数同時荷重印加試験にお いては,この精度に適合するものを選択すればよく, 誤差 の影響はほとんどないと考えられる。

\section{2 試験片の厚さと臨界厚み偏差との関係}

試験片の厚さを変えて, それぞれの厚さのときに厚み偏 差の標準偏差を変えて, ワイブル係数への影響を調べた. その結果, 図 3 と同様にワイブル係数 10 を維持する臨界 厚み偏差があることが分かった．試験片の厚さに対する臨 界厚み偏差の変化を図 4 に示す. 臨界偏差は, 試験片が厚 くなるにつれて大きくなり, 厚さ $0.3 \mathrm{~mm}$ 付近をピークに 小さくなる．これは厚さ $0.3 \mathrm{~mm}$ 付近までは，たわみ变位 が大きくなり, 厚さの誤差による影響を受けにくいが, 試 験片がそれ以上に厚くなると逆にたわぬ变位が小さくなり 厚さの誤差の影響を受けやすくなるためと考えられる。こ の結果から，試験片は厚すぎると曲げ試験においてほとん どたわまないので, 厚さの加工精度を上げることが重要に なることが分かる，逆に試験片が薄すぎると，厚さに対す る誤差の絶対值は小さく, 試験結果に影響を及ぼさない範 囲に加工精度を上げることが困難となる.

\section{3 各セラミックスにおける厚み偏差の影響}

2.2節と同様のシミュレーションを各セラミックスの データ3)を用いて行った. 各セラミックスとも2.2節の結 果と同様に, 厚み偏差の標準偏差が大きくなると臨界厚み 偏差までワイブル係数10を維持するが，それ以降になる

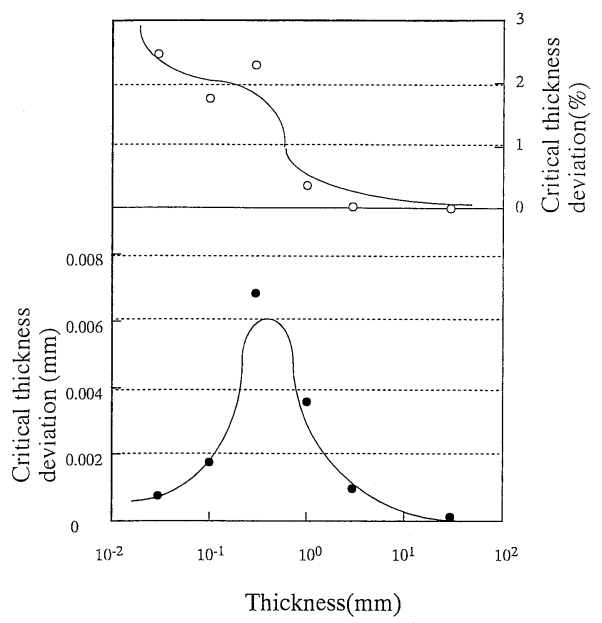

Fig. 4. Change in critical thickness deviation with standard sample thickness for $\mathrm{TiO}_{2}$ ceramics.

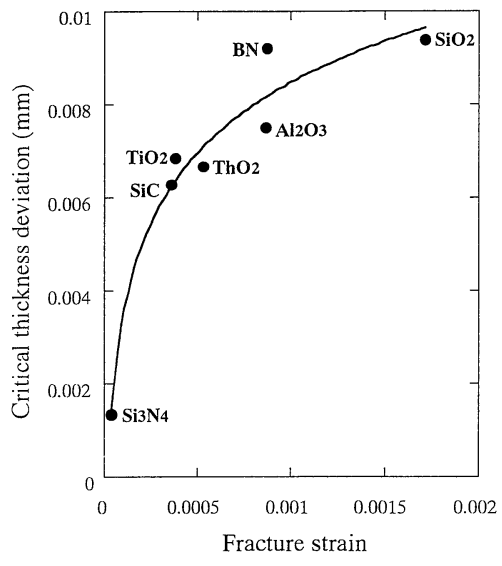

Fig. 5. Relationship between critical thickness deviation and fracture strain for some ceramics.

と厚久偏差の標準偏差の対数に対し直線的に低下した. 各

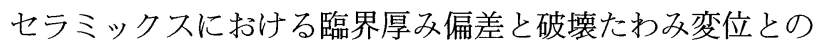
関係を図 5 に示す。破壊たわみ变位と臨界厚み偏差が相関 関係にあることが分かる.

これより臨界厚み偏差内に試験片の厚久偏差がおさまる ように試料片を選択すれば, ワイブル係数への影響はない と考えられる. 試験片の厚さを, マイクロメーターで測定 するとするとばらつきは $0.001 \mathrm{~mm}$ 内で制御できる。これ らセラミックスでは, 臨界厚み偏差が $0.001 \mathrm{~mm}$ より大き いため, 同時荷重印加法において, 真の強度分布形を得る ことは可能であると確認できる.

\section{4. 結 論}

脆性材料であるセラミックスの強度分布の評価方法にお いて, 著者らは複数の試験片を同時に破壊する試験方法を 報告している.この時試験片の厚さが不均一であると, 測 定に誤差が生じてしまう.そこで厚さのばらつきが，見掛 けの強度分布に及ぼす影響を調べた。

チタニアセラミックスを用いたシミュレーションの結 果, ワイブル係数に対して厚み偏差の許容範囲があること が分かった. 更に数種のセラミックスでも, 試験片の厚み 偏差に許容範囲があることが分かった．この許容範囲をマ イクロメーターの測定限界と比較した結果, ほとんどの材 料で厚み偏差はワイブル係数に対して影響のない範囲で抑 えうることが分かった。

また，厚みを変化させた実験により，この臨界厚み偏差 は, 試料片の形状に依存することが分かった. 複数同時荷 重印加試験では, 対象材料の破壊力学特性を考慮し, 試料 片形状を適切に選択することで, 真の強度分布形と同等の ものがより短時間で得られると考えられる.

\section{文 献}

1) A. Kishimoto, K. Sugai et al., J. Am. Ceram. Soc., in press.

2) K. Sugai, A. Kishimoto, Y. Nakamura, N. Motohira and H. Yanagida, J. Ceram. Soc. Japan, 103, 730-32 (1995).

3）日本化学会編, “化学便覧基礎編 I (改訂 3 版)”, 丸善 (1984) p. 536. 